\title{
Preferred and actual retirement age of oral and maxillofacial surgeons aged 55 and older in the Netherlands: a longitudinal study from 2003 to 2016
}

\author{
Joost C. L. den Boer ${ }^{1 *}$ D, Steven A. Zijderveld ${ }^{2,3}$ and Josef J. M. Bruers ${ }^{1,4}$
}

\begin{abstract}
Background: In workforce planning for oral and maxillofacial surgeons in the Netherlands, it is important to plan timely, as these dental specialists are required to earn both medical and dental degrees. An important factor to take into account in workforce planning is the outflow of the profession through retirement. In the workforce planning in the Netherlands, it was assumed that retirement plans are a predictor for the actual moment of retirement. The purpose of this study was to investigate this assumption.

Methods: A standardised survey to investigate the work activity and retirement plans of oral and maxillofacial surgeons was conducted seven times between 2003 and 2016. With some minor variations, in every edition, all oral and maxillofacial surgeons aged 55 years and older who did not indicate to be retired in an earlier edition were invited to participate. The data of all seven editions was analysed to investigate what factors influence the actual retirement age. For the analyses of the data, ANOVA and linear regression were employed.

Results: The response rate was at least $80 \%$ in all editions. For all editions combined, 185 surgeons were invited one or more times, of whom 170 responded at least once. Between 2003 and 2016, the mean preferred retirement age increased from 63.7 to 66.7. Two thirds of the respondents who participated in more than one edition had revised their preferred retirement age upwards. Regarding the difference between preferred and actual retirement age, $45 \%$ of the oral and maxillofacial surgeons retired at a higher age than originally preferred and another 14\% was still working at the age the originally preferred to retire. Linear regression shows that preferred retirement age is associated with sex and the number of working hours and that actual retirement age is associated with preferred retirement age, earlier preference to decrease working hours and working in non-academic hospitals.
\end{abstract}

Conclusion: Altogether, it seems that in this group the preferred retirement age has some predictive value, but the oral and maxillofacial surgeons tend to retire at a higher age than they originally preferred to.

Keywords: Workforce planning, Retirement planning, Preferred retirement age, Actual retirement age, Oral and maxillofacial surgeons

\footnotetext{
* Correspondence: j.den.boer@knmt.nl

'Department of Research, Royal Dutch Dental Association (KNMT), Utrecht,

the Netherlands

Full list of author information is available at the end of the article
}

(c) The Author(s). 2018 Open Access This article is distributed under the terms of the Creative Commons Attribution 4.0 International License (http://creativecommons.org/licenses/by/4.0/), which permits unrestricted use, distribution, and reproduction in any medium, provided you give appropriate credit to the original author(s) and the source, provide a link to the Creative Commons license, and indicate if changes were made. The Creative Commons Public Domain Dedication waiver (http://creativecommons.org/publicdomain/zero/1.0/) applies to the data made available in this article, unless otherwise stated. 


\section{Background}

Between 2000 and 2016, the mean retirement age of employees in the Netherlands increased from 61.0 to 64 . 4 years [1]. This increase applied to employees in all distinct sectors and industries. For health care professionals, the mean retirement age rose from 60.4 years in 2006 to 63.9 years in 2016. Likewise, the mean retirement age of physician specialists, of whom $61 \%$ are selfemployed and thus not employees, has increased from 61.3 years in 2000 to 63.2 years in 2013 [2]. The largest increase occurred between 2006 and 2011 [3]. Although the increase of the mean retirement age seems to have slowed in recent years, it is not inconceivable that the retirement age will rise again. In 2013, the Dutch government implemented the 'general old age pension and pension target age act' (wet verhoging AOW-en pensioenrichtleeftijd). Under this law, the legal retirement age will gradually increase from 65 to 67 years in 2021 and possibly further onwards. The legal retirement age, or the age an individual is eligible for a state pension, will be matched with life expectancy as of 2023 [4]. Life expectancy is expected to increase in the coming years [5].

Deciding on retirement is a complex process in which many factors are involved [6]. The identified factors are financial situation, health, presumed health, working conditions, attitude towards work and retirement and the work situation of one's spouse or partner [7-18]. Feldman and Beehr [19] distinguish three phases in the retirement decision-making process, which are not completely separate and can take place simultaneously. In the first phase-imagining the future-the possibilities of retirement are considered. In the second phaseassessing the past-an individual thinks about when it is time to leave his or her job. In the third phase-transitioning into retirement in the present-the considerations of the first two phases are converted into concrete plans, and action is taken. Solem et al. [20] also distinguish three levels of retirement planning that differ in firmness: considerations, preferences and decisions. They find significant correlations between retirement preferences and actual retirement age as well as between retirement decisions and actual retirement age. They note that this correlation is particularly true for preferences and decisions to retire at a normative age. Furunes et al. [21] conclude, based on a longitudinal, qualitative panel study, employees do not change their retirement plans completely in the last phases of their career, but they do adjust their plans slightly.

Starting from a sufficiently large workforce, an increase in the mean retirement age of an occupational group can have consequences for the succeeding generation, as it can create a surplus of professionals if inflow does not proportionally decrease. On the other hand, if a too high estimation of the retirement age is taken into account in workforce planning, a shortage can emerge. Both a surplus and shortage of doctors can cause unwanted effects. A surplus can lead to inefficiency, overtreatment, unemployment and outmigration. A shortage can result in waitlists and quality loss because the workload is too high and the available time is insufficient to deliver the best quality care [22, 23]. Therefore, an inaccurate estimation of the outflow of professionals can lead to unwanted fluctuations in the number of professionals available for practice [24-26].

A main objective of workforce planning is to prevent unwanted fluctuations [27]. This is especially important in health care, because the education of health care professionals is expensive and takes a long time [28]. In the Netherlands, education costs even more for oral and maxillofacial surgeons (OMFS), as candidate OMFS are required to earn both medical and dental degrees [29]. Both of these educations have 6-year curricula. It is possible to get exemptions from courses, but it is still necessary to plan ahead for the duration of one's specialisation, which is 4 years. Therefore, in workforce planning for OMFS, it is important to adequately consider the expected developments in the demand for and supply of specialists [30]. Therefore, it is necessary to understand when the incumbent professional group will retire. In many countries, workforce planners face difficulties in formulating expectations regarding the retirement of doctors [28]. Additionally, social, cultural, epidemiological and demographic developments should be taken into account [31].

Workforce planning for medical and dental professionals in the Netherlands is exercised by the Capacity Body (CO), which was established in 1999. The main task of the $\mathrm{CO}$ is to assess estimates of the future capacity of health care professionals. The $\mathrm{CO}$ collects empirical data on the supply of health professionals (e.g. the number of professionals, length of working week and task distribution). Moreover, the $\mathrm{CO}$ collects data on the demand for care, including epidemiological information, number of patients and changes in patients' expectations and behaviour. The $\mathrm{CO}$ has different chambers and working groups for different areas of health care, including one for dental specialists, OMFS and orthodontists. Educators and health insurance companies also participate in this working group. Members of the Dutch Society of Oral and Maxillofacial Surgery (NVMKA), the Dutch scientific association for OMFS, and the Royal Dutch Dental Association (KNMT), the main professional association of dentists, OMFS and orthodontists in the Netherlands, represent OMFS. The NVMKA and the KNMT share a common interest and have made contributions to this working group for several decades. In 1994, a committee was established to facilitate this. This committee experienced a lack of 
adequate information on the work activity and intended retirement plans of OMFS. These plans were seen as an indicator for the actual retirement age, as OMFS are self-employed and therefore not bound to the legal retirement age. Therefore, in 2003, a standardised survey was established to investigate the work activity and retirement plans of older OMFS. This survey was repeated several times between 2003 and 2016.

In this manuscript, data from all seven editions of the survey are analysed to answer the following questions. How have the preferred and actual retirement ages of older OMFS developed between 2003 and 2016? To what extent do older OMFS adjust their retirement plans in the last years of their professional careers? What characteristics affect the desired and actual retirement age of older OMFS?

\section{Methods}

In 1996 and 2002, the KNMT conducted two surveys on retirement and retirement plans of OMFS. Both surveys were conducted in different populations of OMFS, and each used a different questionnaire. In 2003, a new questionnaire was developed, which was used in all subsequent surveys. In this questionnaire, OMFS retirement is defined as stopping patient treatment. This is a change of career or employment later in life, which is one of the eight definitions of retirement Denton and Spencer distinguish [32]. The other seven definitions are nonparticipation in the labour force, reduction in hours worked and/or earnings, hours worked or earnings below a minimum, receipt of retirement income, leaving one's main employer, self-assessed retirement and any combination of the former.

Originally, the survey was to be conducted every other year. However, the sixth edition was postponed by several governmental measures [33]. These measures became effective in January 2015 and obliged hospitals, physician specialists and OMFS to develop a new organisational structure [34]. In 2013, OMFS were not expected to oversee the consequences of these measures on their work and retirement situations. As one of the objectives of the survey was to investigate retirement plans, it was considered inefficient to carry out the survey in a time of such uncertainty. Therefore, the sixth edition of the survey was postponed to 2014 in the hope that OMFS would be able to better assess the consequences of the changes.

In contrast to the questionnaire, the research population changed to some extent between editions. In 2003, the survey started with OMFS aged 55 years and older, and in the two subsequent editions, OMFS 50 and older were included. After 2007, the population was once again restricted to those 55 years and older. Until 2016, there was no maximum age. In the last edition, the maximum was set at 79 years. In previous editions, all OMFS aged 80 years and older were retired. Therefore, it was considered undesirable to bother these OMFS with a questionnaire that most likely did not apply to them. In all the editions, the population was invited to participate with the exception of OMFS who indicated being retired in previous editions. For this purpose, the details of all OMFS within the selected age group were retrieved from the dentist database of the KNMT. In this continuously updated database, all dentists and dental specialists are registered, including non-members and retired professionals. The retirees were excluded based on their own indication in an earlier edition of the survey. In all editions, written questionnaires were sent to the OMFS by mail and at least two reminders were sent. However, in 2014, OMFS were given the opportunity to fill in a webbased questionnaire. In this survey, OMFS were asked about their retirement plans.

In all editions of the survey, the response rate was $80 \%$ or greater (Table 1). For all editions combined, 185 OMFS were invited to participate in the survey at least once, of whom 170 (92\%) responded one or more times. More specifically, 37 OMFS participated once (of whom 22 were eligible for participation for

Table 1 Research population and response rates of all editions of the retirement survey among Dutch OMFS aged 55 and older

\begin{tabular}{|c|c|c|c|c|c|}
\hline Edition & Year & Research population $^{a}$ & Number of respondents & Response percentage & Number of respondents still working \\
\hline 1 & 2003 & 61 & 54 & 89 & 48 \\
\hline 2 & 2005 & 64 & 55 & 86 & 50 \\
\hline 3 & 2007 & 65 & 52 & 80 & 52 \\
\hline 4 & 2009 & 76 & 76 & 100 & 68 \\
\hline 5 & 2011 & 89 & 78 & 88 & 76 \\
\hline 6 & 2014 & 123 & 106 & 86 & 78 \\
\hline \multirow[t]{2}{*}{7} & 2016 & 123 & 102 & 83 & 79 \\
\hline & Total $^{\mathrm{b}}$ & 185 & 170 & 92 & \\
\hline
\end{tabular}

${ }^{a}$ All OMFS aged 55 and older were invited to participate in the survey, with the exception of OMFS who indicated being retired in a previous edition. In 2016 , OMFS aged 80 years and older were not invited

${ }^{\mathrm{b}}$ All OMFS were invited to participate in the survey at least once. OMFS who responded to at least one edition of the survey are considered respondents 
the first time in the last edition and 6 indicated to be retired in the first edition), 40 OMFS participated twice, 29 OMFS three times, 24 OMFS four times, 21 OMFS five times, 15 OMFS six times and four OMFS seven times. Almost all respondents (98\%) were male; $2 \%$ were female. Furthermore, 26\% were born in 1944 or earlier, 22\% between 1945 and 1949, 25\% between 1950 and 1954 and $27 \%$ in 1955 or later. The majority of participants were based in the western Netherlands, $17 \%$ in the south, $17 \%$ in the east and $12 \%$ in the north. Overall, 15 OMFS (8\%) did not participate in any edition of the survey. With regard to the individual characteristics mentioned above, the group of non-respondents showed no statistical significant differences $(p<0.05)$ from the 170 OMFS who participated in one or more editions.

The data from the different editions of the survey were merged according to corresponding respondent numbers and were analysed using IBM SPSS Statistics version 24. For the bivariate analyses, ANOVA was used, and for multivariate analyses, stepwise linear regression (minimum $\mathrm{F}$ to enter is .050 and minimum $\mathrm{F}$ to remove is .100) was employed. In the description of the results, a significance level of 0.05 was used.

\section{Results}

In Fig. 1, the counts of the preferred retirement age of the OMFS are shown. The mean preferred retirement age increased from 63.7 in 2003 to 66.7. Figure 2 shows the counts of the actual retirement age of the participants who retired. As OMFS who have retired before are excluded from the research population, these are all newly retirees.
Table 2 shows that 78 (67\%) of the 116 OMFS who reported a preferred retirement age in more than one edition had revised their preferred retirement age upwards, 24 (21\%) did not change their preference and 14 (12\%) adjusted their preferred retirement age downwards. The mean adjustment was +2.1 years.

In Table 3, the differences between preferred and actual retirement age are shown. If an OMFS revised his or her preferred retirement age, the earliest answer is used. The majority of the 51 pensioned OMFS retired later than originally intended, 11 retired at the age they initially preferred and 11 retired at a younger age. The mean difference was +1.4 years. Furthermore, 14 OMFS were still active after the age they originally preferred to retire.

Table 4 shows the results of the bivariate analyses, in which individual characteristics are related to preferred and actual retirement age. The table indicates that OMFS aged 55 to 59 and OMFS aged 60 to 64 prefer to retire at a younger age than both OMFS aged 65 and older. Moreover, OMFS who work in academic hospitals prefer to retire at an older age than OMFS who work in other settings, and OMFS who work seven dayparts (morning, afternoon or evening) a week or less prefer to retire at younger age than OMFS who work eight or more dayparts per week. Further, OMFS who prefer to retire at age 59 or younger actually retired at younger age than OMFS who prefer to retire at an older age. OMFS who prefer to decrease their amount of working hours retired at a younger age than OMFS who did not, and OMFS who worked in non-academic hospitals retired at an older age than their colleagues who did not.

The results of the multivariate analyses are included in Tables 5 and 6 . Table 5 shows that female OMFS

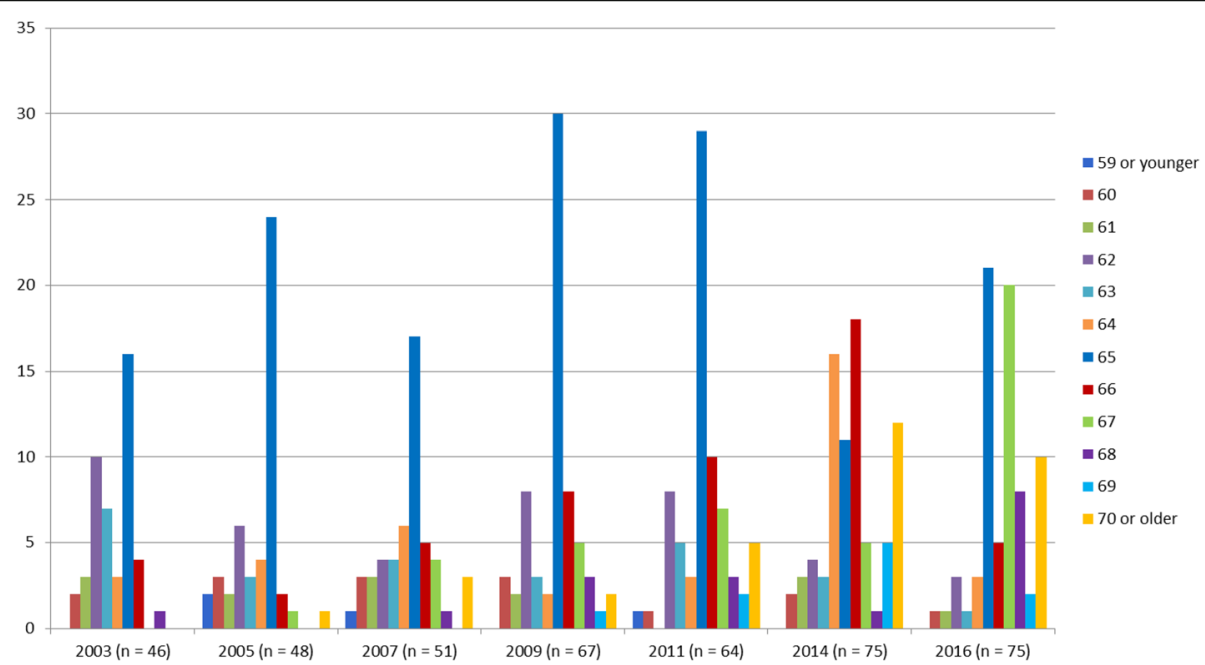

Fig. 1 Counts of the preferred retirement age of Dutch OMFS 55 years and older between 2003 and 2016 


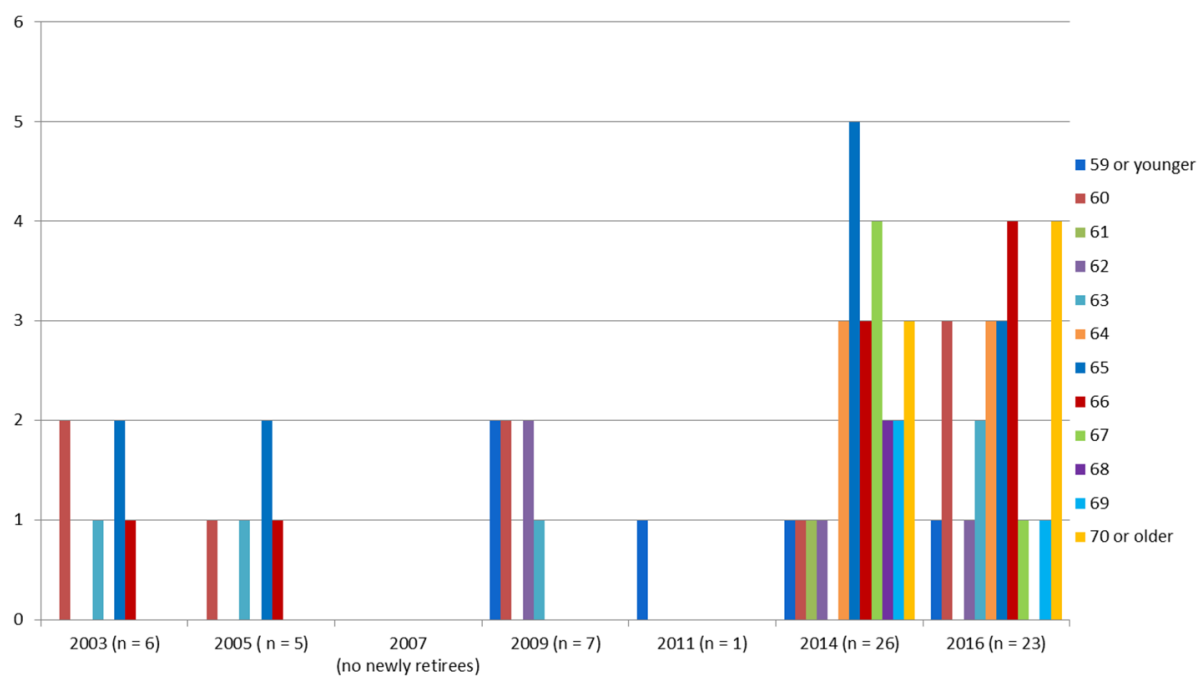

Fig. 2 Counts of the actual retirement age of newly retired Dutch OMFS 55 years and older between 2003 and 2016

prefer to retire when they are almost 5 months older (0.39 years) than their male colleagues do. Furthermore, the more hours per week OMFS work, the older they prefer to retire.

With regard to the actual age OMFS retired, Table 6 indicates that the higher the preferred retirement age, the higher the actual retirement age. For every increase of the preferred retirement age by 1 year, the actual retirement age, which basically is higher, increases more than 7 months (0.61 years). Furthermore, OMFS who indicated preferring to decrease their working hours in an earlier edition retired at a younger age than OMFS who did not prefer this. In addition, OMFS who used to work in non-academic hospitals retired at an older age than OMFS who only worked in academic hospitals and/or other kinds of practices. The explanatory power of the first model is rather low $\left(R^{2}=0.15\right)$. In the model for

Table 2 Difference between preferred retirement age of Dutch OMFS of 55 years and older who participated in two or more editions of the retirement survey

\begin{tabular}{llll}
\hline & Number & Percentage & Difference (years) \\
\hline $\begin{array}{l}\text { Adjusted preferred retirement } \\
\text { age downwards }\end{array}$ & 14 & 12 & -2.0 \\
$\begin{array}{l}\text { Did not adjust preferred } \\
\text { retirement age }\end{array}$ & 24 & 21 & 0.0 \\
$\begin{array}{l}\text { Adjusted preferred retirement } \\
\text { age upwards }\end{array}$ & 78 & 67 & 3.5 \\
Total & 116 & 100 & 2.1 \\
\hline
\end{tabular}

If an OMFS indicated a preferred retirement age in more than two editions, the difference between them was calculated. The difference between preferred retirement ages in different editions is expressed in years. A positive score indicates the OMFS adjusted the preferred retirement age upwards, and a negative score indicates the OMFS adjusted the preferred retirement age downwards actual retirement age, the explanatory power is somewhat higher $\left(R^{2}=0.33\right)$.

\section{Discussion}

Between 2003 and 2016, the preferred retirement age of 'older' OMFS gradually increased. On the other hand, the increase in actual retirement age is less clear. This presumably has to do with the small size of the research population. In spite of the fact that in all editions the entire population of older OMFS was solicited for the survey and that the response rates were high, the actual number of participants is still rather low. In total, 170 OMFS participated in one or more surveys, 51 of whom retired at some point. When the total number of respondents in a category is this low, the influence of outlier values can be significant. These outliers can be explained by several factors, such as data recording or entry errors, sampling errors, environmental conditions and motivated misreporting [35]. Due to the small sample size

Table 3 Difference between preferred and actual retirement age of Dutch OMFS of 55 years and older who retired between participation two editions of the survey

\begin{tabular}{llll}
\hline & Number & Percentage & Difference (years) \\
\hline $\begin{array}{l}\text { Retired younger than first } \\
\text { preferred retirement age }\end{array}$ & 11 & 17 & -3.4 \\
$\begin{array}{l}\text { Retired at first preferred } \\
\text { retirement age }\end{array}$ & 11 & 17 & 0.0 \\
$\begin{array}{l}\text { Retired older than first } \\
\text { preferred retirement age }\end{array}$ & 29 & 45 & 3.7 \\
Total & 51 & 100 & 1.4 \\
\hline
\end{tabular}

${ }^{a}$ The difference between preferred and actual retirement age is expressed in years. A positive score indicates the OMFS retired older than first preferred, and a negative score indicates the OMFS retired younger than first preferred 
Table 4 Mean preferred and actual retirement age of Dutch OMFS aged 55 years and older, in relation to individual characteristics

\begin{tabular}{|c|c|c|c|c|}
\hline & Preferred retirement age $(N)^{a}$ & & Actual retirement age $(N)$ & \\
\hline \multicolumn{5}{|l|}{ Sex } \\
\hline Male & $64.0(143)$ & & $64.4(67)$ & \\
\hline Female & $66.0(4)$ & & & \\
\hline $\mathrm{Age}^{\mathrm{a}}$ & & * & & \\
\hline 59 years or younger & $64.0(126)$ & & Not applicable & \\
\hline $60-64$ years & $64.4(20)$ & & Not applicable & \\
\hline 65 years or older & $70.0(1)$ & & Not applicable & \\
\hline \multicolumn{5}{|l|}{ Region located ${ }^{a}$} \\
\hline North & $64.5(20)$ & & $64.3(7)$ & \\
\hline East & $64.4(25)$ & & $64.8(8)$ & \\
\hline South & $63.5(25)$ & & $64.3(12)$ & \\
\hline West & $64.1(73)$ & & $64.6(38)$ & \\
\hline Working in an academic hospital ${ }^{a, b}$ & & * & & \\
\hline Yes & $64.7(41)$ & & $64.0(15)$ & \\
\hline No & $63.8(105)$ & & $65.1(39)$ & \\
\hline Working in a non-academic hospital ${ }^{a, b}$ & & & & * \\
\hline Yes & $64.0(119)$ & & $65.4(43)$ & \\
\hline No & $64.5(27)$ & & $62.5(11)$ & \\
\hline \multicolumn{5}{|l|}{ Working in another setting ${ }^{\mathrm{a}, \mathrm{b}}$} \\
\hline Yes & $64.2(42)$ & & $64.1(18)$ & \\
\hline No & $64.0(104)$ & & $65.2(38)$ & \\
\hline Dayparts per week working a & & $* * *$ & & \\
\hline 7 or less & $62.9(34)$ & & $64.1(20)$ & \\
\hline $8-9$ & $64.0(43)$ & & $65.0(10)$ & \\
\hline 10 or more & $64.7(69)$ & & $64.8(21)$ & \\
\hline Prefer to decrease working hours ${ }^{a}$ & & & & * \\
\hline Yes & $63.8(40)$ & & $62.4(14)$ & \\
\hline No & $64.2(106)$ & & $65.7(40)$ & \\
\hline \multicolumn{5}{|l|}{ Decreased working hours ${ }^{c}$} \\
\hline Yes & Not applicable & & $65.0(22)$ & \\
\hline No & Not applicable & & $64.7(32)$ & \\
\hline Preferred retirement age ${ }^{a}$ & & & & * \\
\hline 59 years or younger & Not applicable & & $58.0(2)$ & \\
\hline $60-64$ years & Not applicable & & $64.5(31)$ & \\
\hline 65 years or older & Not applicable & & $65.3(8)$ & \\
\hline Total & $64.1(147)$ & & $64.4(67)$ & \\
\hline
\end{tabular}

${ }^{*} p<0.05 ;{ }^{* *} p<0.01 ;{ }^{* * *} p<0.001$

a If an OMFS revised his or her preference or if the actual situation changed in between editions, the first answer is used. For age and location, the situation at the first participation is used

${ }^{b}$ It is possible that an OMFS works in different hospitals and/or settings

'Between participations in different editions of the OMFS retirement survey. An OMFS who indicated to work 10 dayparts per week in the first edition of the survey and eight dayparts per week in the second edition, decreased working hours by two dayparts

and the limited number of variables, it is possible to check all data for entry errors and make corrections. Sampling errors cannot be the cause of deviant values in this survey, as the entire population was solicited. Non- response bias can be a determinant of errors [36]. However, the available individual background characteristics do not show differences between the 170 respondents and the 15 non-respondents. The possibility that 
Table 5 Association between preferred retirement age and individual characteristics of Dutch OMFS aged 55 years and older $(n=$ 146)

\begin{tabular}{|c|c|c|c|c|c|c|}
\hline & $B$ & Standard error & $\beta$ & Tolerance & VIF & $p$ \\
\hline Constant & 60.87 & 0.73 & & & & \\
\hline Female & 0.39 & 0.08 & 0.16 & 1.00 & 1.00 & $0.04^{*}$ \\
\hline Dayparts per week working & 2.17 & 1.06 & 0.36 & 1.00 & 1.00 & $0.00^{* * *}$ \\
\hline \multicolumn{7}{|l|}{$R^{2}=0.15$} \\
\hline Durbin-Watson = 1.63 & & & & & & \\
\hline
\end{tabular}

The following individual characteristics were considered in the analyses: sex, age at first participation, region located, work setting, dayparts per week working and preference to decrease working hours. Only the statistically significant associations are displayed. If an OMFS revised his or her preference or if the actual situation changed in between editions, the first answer is used

${ }^{*} p<0.05 ;{ }^{* *} p<0.01 ;{ }^{* * *} p<0.001$

environmental conditions influenced the results was recognised. After all, one edition of the survey was postponed due the effects of governmental measures regarding the work situations of OMFS. Obviously, it is possible that deviant values are caused by intended or unintended misreporting or by the fact that there are OMFS that have considerably different retirement plans than their colleagues. Altogether, we tentatively conclude that the preferred and actual retirement age have increased since 2003.

Between 2003 and 2016, the research population increased from 61 to 123 , due to the age composition of the population of OMFS in the Netherlands. Data from the KNMT dentist database suggest that the population of OMFS 55 and older will increase further until at least 2020. The increase of the population can partly explain the increase in number of OMFS who indicated to be retired in the last two editions of the survey. Other factors of possible influence are the fact that the 2014 editions followed an edition in which a rather small number OMFS indicated to be retired; the interval between the fifth and sixth edition was a year longer than usual and an increase of retirement age. The latter can be the result of the increase of the legal retirement age, although OMFS are self-employed and therefore are not bound to the legal retirement age.

The results of the seven editions of the survey indicate that OMFS adjust their retirement plans in the last years of their professional careers. Most OMFS who did so adjusted their preferred retirement age upwards. Furthermore, OMFS who have retired generally stopped treating patients at an older age than they originally indicated as their preferred retirement age. This should be taken into account when using the preferred retirement age for capacity planning to avoid high costs for training a surplus of OMFS. In the survey, unretirement was not taken into account, as retired OMFS were excluded for the following editions. Although unretirement is not uncommon, economic factors play an important role in the decision to unretire [37-39]. These factors are not applicable in the Netherlands [40]. Furthermore, the post-retirement jobs differ from the pre-retirement jobs and appear to be less demanding [38]. Therefore, it was concluded that unretirement as an OMFS is rare in the Netherlands.

The rationale for the survey was to gain insight into the outflow of OMFS. Solem et al. [20] conclude that

Table 6 Association between actual retirement age and individual characteristics of Dutch OMFS aged 55 years and older who retired between editions of the retirement survey $(n=51)$

\begin{tabular}{|c|c|c|c|c|c|c|}
\hline & $B$ & Standard error & $\beta$ & Tolerance & VIF & $p$ \\
\hline Constant & 24.33 & 13.39 & & & & \\
\hline Working in a non-academic hospital ${ }^{a}$ & 3.61 & 1.17 & 0.37 & 0.95 & 1.05 & $0.00^{* * *}$ \\
\hline Prefer to decrease working hours ${ }^{b}$ & -3.41 & 1.08 & -0.38 & 0.95 & 1.05 & $0.00^{* * *}$ \\
\hline Preferred retirement age ${ }^{c}$ & 0.61 & 0.21 & 0.34 & 0.99 & 1.01 & $0.01^{* *}$ \\
\hline \multicolumn{7}{|l|}{$R^{2}=0.34$} \\
\hline Durbin-Watson $=1.79$ & & & & & & \\
\hline
\end{tabular}

The following individual characteristics were considered in the analyses: sex, region located, work setting, dayparts per week working, decreased working hours and preferred retirement age. Only the statistically significant associations are displayed ${ }^{*} p<0.05 ;{ }^{* *} p<0.01 ;{ }^{* * *} p<0.001$

a Dummy variable. It is possible that an OMFS works in different hospitals and/or settings

${ }^{b}$ This indicates that an OMFS suggested in an earlier edition of the survey to prefer to decrease working hours

' If an OMFS revised his or her preference or if the actual situation changed in between editions, the first answer is used 
the preferred retirement age is a particularly powerful predictor of actual retirement age when it corresponds with a normative retirement age. For many years, in the Dutch pension system, the normative retirement age was 65 years. However, the normative retirement age will increase to 67 years in 2021 and will probably increase more thereafter. From 2003 to 2011, the mode of preferred retirement age of older OMFS was 65; in 2014, it was 67. In 2016, the mode was 65 again, but there were two peaks in preferred retirement age: 21 OMFS planned to stop at 65,20 planned to stop at 67 and all other ages were mentioned by eight OMFS or fewer. It is expected that the mean pension age of OMFS will increase in the coming years.

Due to the rationale of the survey, the questionnaire was short. As a result, the available data did not give overwhelming insights into the characteristics and factors that affect preferred and actual retirement ages. It seems, however, that the preferred retirement age is a valid and reliable predictive factor for actual retirement age.

Even in this small, homogenous group of highly educated health care professionals, it seems that more factors than the ones included in the survey affect retirement age. From the literature, it is evident that financial situation, health, presumed health, working conditions, attitude towards work and retirement and the work situation of one's spouse or partner are important factors [7-18]. An extensive questionnaire covering all these factors did not fit within the scope of the survey, which was designed to give a quick view of retirement plans without further investigation into the context. To accomplish this, a high response rate was desired. Jepson et al. [41] demonstrate that questionnaire length affected the response rate for a mailed survey of generalist physicians; shorter questionnaires got higher response rates. This short questionnaire indeed accomplished high response rates of $80 \%$ or greater.

Another factor that was not investigated is the reason for the adjustment of retirement age. Adjustments can be voluntary after reconsideration or involuntary, for example, when poor health prevents an OMFS from continuing work [42]. As some conditions can appear abrupt, this can immediately influence the predictive power of the preferred retirement age for that individual. Therefore, the actual retirement age can only be forecasted by preferences to some extent.

Despite these observations, the survey data helped KNMT and NVMKA in developing a point of view on future training places. As said, OMFS are a very specific group of highly educated professionals. Therefore, the results cannot be generalised for all occupational groups. On the other hand, all physicians are highly educated professionals and in the Netherlands many medical specialists work in settings comparable to the working settings of OMFS.

\section{Conclusions}

Altogether, it seems that for older OMFS the preferred retirement age has predictive value for outflow from the profession in the coming years. It should be noted that OMFS tend to retire at a somewhat higher age than they originally prefer to.

\section{Abbreviations}

ACTA: Academic Centre for Dentistry Amsterdam; CO: Capacity Body; KNMT: Royal Dutch Dental Association; NVMKA: Dutch Society of Oral and Maxillofacial Surgery; OMFS: Oral and maxillofacial surgeons

\section{Funding}

The study was funded by KNMT

\section{Availability of data and materials}

The datasets analysed for this study are available from the corresponding author on reasonable request.

\section{Authors' contributions}

JDB edited the questionnaire, performed the statistical analyses and drafted the manuscript. SZ edited the manuscript. JB edited the questionnaire and the manuscript. All authors have read and approved the manuscript.

\section{Ethics approval and consent to participate}

The study protocol was approved by an independent review board of KNMT. In all editions, oral and maxillofacial surgeons eligible for participation received a letter in which the survey was announced and its background explained. By completion and returning questionnaire (by freepost or e-mail), oral and maxillofacial surgeons consented participation. Data were anonymized before analyses. Information that could be traced back to the oral and maxillofacial surgeon who answered the questions was only used for the analyses of the representativeness and for the inclusion or exclusion in later editions.

\section{Competing interests}

The authors declare that they have no competing interests.

\section{Publisher's Note}

Springer Nature remains neutral with regard to jurisdictional claims in published maps and institutional affiliations.

\section{Author details}

${ }^{1}$ Department of Research, Royal Dutch Dental Association (KNMT), Utrecht, the Netherlands. 'Department of Oral and Maxillofacial Surgery, St Antonius Hospital, Nieuwegein, the Netherlands. ${ }^{3}$ Department of Oral and Maxillofacial Surgery, St Antonius Hospital, Utrecht, the Netherlands. ${ }^{4}$ Academic Centre for Dentistry Amsterdam (ACTA), University of Amsterdam and Vrije Universiteit, Department of Social Dentistry and Behavioural Sciences, Amsterdam, the Netherlands.

Received: 30 November 2017 Accepted: 2 May 2018

Published online: 30 May 2018

\section{References}

1. Centraal Bureau voor de Statistiek. Pensioenleeftijd werknemers in 2016 niet gestegen: Centraal Bureau voor de Statistiek; 2017 Available from: https://www. cbs.nl/nl-nl/nieuws/2017/12/pensioenleeftijd-werknemers-in-2016-niet-gestegen.

2. Centraal Bureau voor de Statistiek. Medisch geschoolden; arbeidspositie, positie in de werkkring, naar beroep: CBS; 2017. Available from: http:// statline.cbs.nl/Statweb/publication/?DM=SLNL\&PA=81551ned\&D1=19$22 \& D 2=0 \& D 3=0 \& D 4=6 \& D 5=13-16 \& H D R=T \& S T B=G 1, G 2, G 3, G 4 \& W=T$. Accessed 15 May 2018.

3. Capaciteitsorgaan. Capaciteitsplan 2016: Voor de medische, klinisch technologische, geestelijke gezondheid, FZO en aanverwante (vervolg)opleidingen. Utrecht: Capaciteitsorgaan; 2016.

4. Wet verhoging AOW- en pensioenrichtleeftijd, (2012) http://wetten. overheid.nl/BWBR0031799/2016-01-01. Accessed 15 May 2018. 
5. Van Duin C, Stoeldraijer L. Bevolkingsprognose 2014-2060: groei door migratie. 2014.

6. Fisher $G$, Chaffee D, Sonnega A. Retirement timing: a review and recommendations for future research. Work Aging Retirement. 2016;2(2):230-61.

7. Beehr T, Glazer S, Nielson N, Farmer S. Work and nonwork predictors of employees' retirement ages. J Vocat Behav. 2000;57(2):206-25.

8. Van Droogenbroeck F, Spruyt B. To stop or not to stop: an empirical assessment of the determinants of early retirement among active and retired senior teachers. Res Aging. 2014;36(6):753-77.

9. Nilsson K, Hydbom A, Rylander L. How are self-rated health and diagnosed disease related to early or deferred retirement? A cross-sectional study of employees aged 55-64. BMC Public Health. 2016;16(1):886.

10. De Preter H, Van Looy D, Mortelmans D. Individual and institutional push and pull factors as predictors of retirement timing in Europe: a multilevel analysis. J Aging Stud. 2013;27(4):299-307.

11. Bamberger $P$, Bacharach S. Predicting retirement upon eligibility: an embeddedness perspective. Hum Resour Manag. 2014;53(1):1-22.

12. Riedel $\mathrm{M}, \mathrm{Hofer} \mathrm{H}$, Wögerbauer B. Determinants for the transition from work into retirement in Europe. IZA J Eur Labor Stud. 2015;4(1):4.

13. Davies E, Van der Heijden B, Flynn M. Job satisfaction, retirement attitude and intended retirement age: a conditional process analysis across workers' level of household income. Front Psychol. 2017:8:891.

14. Warren D. Retirement decisions of couples: the impact of spousal characteristics and preferences on the timing of retirement. Melbourne: Melbourne Institute; 2013. Report No.: Working Paper No. 41/13

15. Moen P. Retirement dilemmas and decisions. 2012

16. Wang M, Shi J. Psychological research on retirement. Annu Rev Psychol. 2014;65:209-33.

17. Prothero J, Beach L. Retirement decisions: expectation, intention, and action. J Appl Psychol. 1984;14(2):162-74.

18. Carr E, Hagger-Johnson G, Head J, Shelton N, Stafford M, Stansfeld S, et al. Working conditions as predictors of retirement intentions and exit from paid employment: a 10-year follow-up of the English longitudinal study of ageing. Eur J Ageing. 2016;13:39-48.

19. Feldman D, Beehr T. A three-phase model of retirement decision making. Am Psychol. 2011;66(3):193-203.

20. Solem P, Syse A, Furunes T, Mykletun R, De Lange A, Schaufeli W, et al. To leave or not to leave: retirement intentions and retirement behaviour. Ageing Soc. 2016;36(2):259-81.

21. Furunes T, Mykletun R, Solem P, de Lange A, Syse A, Schaufeli W, et al. Late career decision-making: a qualitative panel study. Work Aging Retirement. 2015;1(3):284-95.

22. Lopes M, Almeida A, Almada-Lobo B. Handling healthcare workforce planning with care: where do we stand? Hum Resour Health. 2015;13:38.

23. Roberfroid D, Leonard C, Stordeur S. Physician supply forecast: better than peering in a crystal ball? Hum Resour Health. 2009;7:10.

24. Van Greuningen M. Health workforce planning in the Netherlands. Utrecht: Tilburg University; 2016.

25. McPake B, Maeda A, Araújo E, Lemiere C, El Maghraby A, Cometto G. Why do health labour market forces matter? Bull World Health Organ. 2013;91(11):841-6.

26. Dussault G, Dubois C-A. Human resources for health policies: a critical component in health policies. Hum Resour Health. 2003;1 (1):1.

27. Van Greuningen $M$, Batenburg $R$, Van der Velden $L$. The accuracy of general practitioner workforce projections. Hum Resour Health. 2013;11:31.

28. Ono T, Lafortune G, Schoenstein M. Health workforce planning in OECD countries: a review of 26 projection models from 18 countries. Paris: Organization for Economic Cooperation and Development; 2013. Report No.: 1815-2015 Contract No.: 62

29. College Tandheelkundige Specialismen, Nederlandse Maatschappij tot bevordering der Tandheelkunde. Besluit Mondziekten, Kaak- en Aangezichtschirurgie 2013. Nieuwegein: CTS; 2013.

30. Jambroes M. The public health workforce [PhD]. Amsterdam: University of Amsterdam; 2015

31. Kuhlmann E, Batenburg R, Dussault G. Health workforce governance in Europe: where are we going? Health Policy. 2015;119(12):1515-6.

32. Denton F, Spencer B. What is retirement? A review and assessment of alternative concepts and measures. Can J Aging. 2009;28(1):63-76.
33. Ministerie van Volksgezondheid Welzijn en Sport. Kamerbrief over invoering integrale bekostiging medisch specialistische zorg 2013. Available from: https://www.zorgkennis.net/downloads/kennisbank/ZK-kennisbankKamerbrief-over-invoering-integrale-bekostiging-medisch-specialistischezorg-2151.pdf. Accessed 15 May 2018.

34. Zorgmarkten. De stand van de MKA-chirurgie: De regulering, organisatie en financiering van de Mondziekten, Kaak- en Aangezichtschirurgie in Nederland. (interne rapportage). Veenendaal: Zorgmarkten; 2016.

35. Osborne J, Overbay A. The power of outliers (and why researchers should always check for them). Pract Assess Res Eval. 2004;9(6). http://pareonline. net/htm/v9n6.htm. Accessed 15 May 2018.

36. Berg N. Non-response bias. In: Kempf-Leonard K. (ed.). Encyclopedia of Social Measure. 2005; Vol. 2: pp. 865-73.

37. Gonzales G. An examination on un-retirement: retirees returning to work: Washington University in St. Louis; 2013.

38. Maestas N. Back to work expectations and realizations of work after retirement. J Hum Resour. 2010;45(3):718-48.

39. Cahill K, Giandrea M, Quinn J. Reentering the labor force after retirement. Mon Labor Rev. 2011;134(6):34-42.

40. Bloemen H, Hochguertel S, Zweerink J. Gradual retirement in the Netherlands: an analysis using administrative data. Res Aging. 2016:38(2):202-33.

41. Jepson C, Asch D, Hershey J, Ubel P. In a mailed physician survey, questionnaire length had a threshold effect on response rate. J Clin Epidemiol. 2005;58(1):103-5.

42. Beehr T. The process of retirement: a review and recommendations for future investigation. Pers Psychol. 1986;39(1):31-55.

\section{Ready to submit your research? Choose BMC and benefit from:}

- fast, convenient online submission

- thorough peer review by experienced researchers in your field

- rapid publication on acceptance

- support for research data, including large and complex data types

- gold Open Access which fosters wider collaboration and increased citations

- maximum visibility for your research: over $100 \mathrm{M}$ website views per year

At BMC, research is always in progress.

Learn more biomedcentral.com/submissions 